\title{
Specific PCR Detection of Fusarium oxysporum f. sp. vasinfectum California Race 4 Based on a Unique Tfo1 Insertion Event in the PHO Gene
}

Carlos S. Ortiz, Department of Plant Pathology and Microbiology, Texas A\&M University, College Station 77845; Alois A. Bell, Southern Plains Agricultural Research Center, United States Department of Agriculture-Agricultural Research Service (USDA-ARS), College Station, TX 77845; Clint W. Magill, Department of Plant Pathology and Microbiology, Texas A\&M University; and Jinggao Liu, Southern Plains Agricultural Research Center, USDA-ARS

\begin{abstract}
A highly virulent race 4 (Cal race 4 ) of Fusarium oxysporum f. sp. vasinfectum was identified in California cotton fields in 2001, and has since been found in increasing numbers of fields. Cal race 4 isolates contain a unique $T f o 1$ transposon insertion in the $P H O$ gene that was not found in other $F$. oxysporum f. sp. vasinfectum genotypes. Based on this insertion, a multiplex polymerase chain reaction method was developed to detect the Cal race 4 pathogen. A panel of $F$. oxysporum $\mathrm{f}$. sp. vasinfectum isolates representing different vegetative compatibility groups (VCG) and DNA sequence types was assembled to test the specificity of the detection method. In all, 16 of $17 \mathrm{Cal}$ race 4 isolates produced a 583-bp amplicon; the other isolate produced a 396-bp amplicon reflecting the

absence of the $T f o 1$ insertion. This isolate was a moderately virulent pathogen among Cal race 4 isolates. In total, 80 other $F$. oxysporum isolates associated with cotton and 11 other formae speciales of $F$. oxysporum produced only the 396-bp amplicon. The method also distinguished $\mathrm{Cal}$ race 4 isolates from India race 4 isolates and China race 7 isolates, which did not possess the unique Tfol insertion but otherwise had identical DNA sequences, and all belong to VCG0114. The method is capable of detecting the pathogen directly from infected stem tissues even before external symptom appears and, thus, provides an effective tool for timely identification of infested fields and seed lots, and should help reduce dissemination of $\mathrm{Cal}$ race 4 in the U.S. Cotton Belt.
\end{abstract}

Members of the Fusarium oxysporum species complex are common soil saprophytes, but are best known as vascular wilt and root rot pathogens in a broad range of plant species (Di Pietro et al. 2003; Gordon and Martyn 1997). Isolates have been subclassified into formae speciales based on their host range which generally is very limited (Snyder and Hansen 1940). Those isolates that attack cotton (Gossypium spp.) were designated as $F$. oxysporum $\mathrm{f}$. sp. vasinfectum W. C. Snyder \& H. N. Hansen. Isolates within F. oxysporum f. sp. vasinfectum have further been categorized into races based on their differential virulence to host genotypes (Armstrong and Armstrong 1960). Eight races have been designated thus far: races 1 and 2 from the United States, race 3 from Egypt, race 4 from India, race 5 from Sudan, race 6 from Brazil, and races 7 and 8 from China (Armstrong and Armstrong 1960, 1978; Armstrong and Armstrong 1958; Chen et al. 1985; Ibrahim 1966). Though the validity of race designations within $F$. oxysporum f. sp. vasinfectum is currently being challenged (Davis et al. 1996; Davis et al. 2006), these race designations are still in use today in literature, often based not on race concept but on DNA sequence identity or similarity with the reference race isolates. For example, "California race 3" isolates was much less virulent than the original India race 3 on Gossypium barbadense and their DNA sequences differed from that of Indian race 3 (Kim et al. 2005). Furthermore, race 5 was retracted when pathogenicity tests on cotton differential hosts and culture phenotypes indicated that it was identical to race 3 (Nirenberg et al. 1994). DNA sequence analysis also

Correspondence author: J. Liu; E-mail: Jinggao.Liu@ ars.usda.gov

The mention of firm names or trade products does not imply that they are endorsed or recommended by the United States Department of Agriculture (USDA) over other firms or similar products not mentioned. The USDA is an equal opportunity provider and employer.

*The $\boldsymbol{e}$-Xtra logo stands for "electronic extra" and indicates that two supplementary tables are published online.

Accepted for publication 20 June 2016.

This article is in the public domain and not copyrightable. It may be freely reprinted with customary crediting of the source. The American Phytopathological Society, 2017. confirmed that race 5 was indistinguishable from race 3 (Skovgaard et al. 2001).

Due to confusion and conflicts in the uniform application of the race concept within the currently available differential hosts, no more new races have been erected in recent decades (Davis et al. 1996; Holmes et al. 2009). Instead, new isolates have been simply designated as genotypes or biotypes based on DNA sequencing or biochemical characterization, respectively. Genetic variations among races, new biotypes, and genotypes have been assessed by DNA sequence and vegetative compatibility group (VCG) analyses (Davis et al. 1996; Fernandez et al. 1994; Kim et al. 2005; Skovgaard et al. 2001). Vegetative compatibility is governed by a number of vic loci in filamentous fungi and requires all the alleles at each locus to be the same in two compatible isolates (Leslie 1993). Thus, isolates in the same VCG may represent a clonal lineage in an asexual population such as $F$. oxysporum, or at least indicate close genetic relatedness (Puhalla 1985). Therefore, VCG analysis can provide a fine fingerprint of the isolates but lacks genetic relatedness information between two different VCG. Genomic information, obtained from limited stretches of sequences, may lack sufficient resolution to distinguish different VCG but reveals genetic relationships among VCG. Thus, combining these two analyses can provide very powerful tools to categorize different pathogenic $F$. oxysporum f. sp. vasinfectum isolates.

In 2001, highly virulent $F$. oxysporum f. sp. vasinfectum isolates were observed in Pima cotton ( $G$. barbadense) on the west side of the San Joaquin Valley of California (Kim et al. 2005). These $F$. oxysporum f. sp. vasinfectum isolates occurred on heavy soils and did not require nematodes to cause severe disease. The newly found isolates were subsequently identified and designated as $\mathrm{Cal}$ race 4 based on sequence match to the race 4 reference isolate from India. The original race 4 from India was reported to infect cultivars of $G$. arboreum but not those of $G$. barbadense and $G$. hirsutism (Armstrong and Armstrong 1960). Race 4 in California also infected Upland cotton ( $G$. hirsutum) varieties but with less severity (Kim et al. 2005). Race 7 from China had identical sequences compared with race 4 from India and California within three partial nuclear genes studied (Kim et al. 2005; Skovgaard et al. 2001) and caused disease in cultivars of $G$. hirsutum, G. barbadense, and G. arboreum (Chen et al. 1985). "Race 4-like" F. oxysporum f. sp. vasinfectum isolates were reported from Alabama and Mississippi 
Table 1. Fungal isolates used in this study

\begin{tabular}{|c|c|c|c|c|c|}
\hline \multirow[b]{2}{*}{ Isolate } & \multirow[b]{2}{*}{ Race; VCG ${ }^{\mathbf{b}}$} & \multirow[b]{2}{*}{ Origin } & \multirow[b]{2}{*}{ Source } & \multicolumn{2}{|c|}{ Multiplex PCR ${ }^{\mathbf{a}}$} \\
\hline & & & & FovT-R & FovP-R \\
\hline \multicolumn{6}{|l|}{ F. oxysporum from cotton } \\
\hline \multicolumn{6}{|l|}{ Races 1, 2, 6 lineage $\mathrm{e}^{\mathrm{c}}$} \\
\hline ATCC16421 & $1 ; 0111$ & South Carolina & G. M. Armstrong & - & + \\
\hline AuSeed 23 & $\ldots ; \ldots$ & Australia & Liu et al. 2011 & - & + \\
\hline CDR238 & $\ldots ; 01114$ & Arkansas & This study & - & + \\
\hline ATCC36198 & $6 ; 0116$ & Brazil & G. M. Armstrong & - & + \\
\hline CDR977 & $\ldots ; 01115$ & Alabama & This study & - & + \\
\hline CDR982 & $\ldots ; 01115$ & Alabama & This study & - & + \\
\hline CDR1034 & $\ldots ; 01115$ & Texas & This study & - & + \\
\hline CDR960 & $\ldots ; 01116$ & Alabama & This study & - & + \\
\hline CDR965 & $\ldots ; 01116$ & Alabama & This study & - & + \\
\hline ATCC46644 & $\ldots ; 01117 \mathrm{~A}$ & California & G. M. Armstrong & - & + \\
\hline KL11-202 & $\ldots ; 01117 \mathrm{~A}$ & Alabama & K. S. Lawrence & - & + \\
\hline CA-10 & $\ldots ; 01117 \mathrm{~A}$ & Kern Co., CA & Kim et al. 2005 & - & + \\
\hline CDR194 & $\ldots ; 01117 \mathrm{~A}$ & Florida & This study & - & + \\
\hline CDR43 & $\ldots ; 01117 \mathrm{~A}$ & Louisiana & This study & - & + \\
\hline CDR5 & $\ldots ; 01117 \mathrm{~A}$ & Mississippi & This study & - & + \\
\hline CDR219 & $\ldots ; 01117 \mathrm{~A}$ & North Carolina & This study & - & + \\
\hline CDR1023 & $\ldots ; 01117 \mathrm{~A}$ & Texas & This study & - & + \\
\hline CDR166 & $\ldots ; 01117 \mathrm{~B}$ & Alabama & This study & - & + \\
\hline CDR4 & $\ldots ; 01117 \mathrm{~B}$ & California & This study & - & + \\
\hline CDR84 & $\ldots ; 01117 \mathrm{~B}$ & Georgia & This study & - & + \\
\hline CDR235 & $\ldots ; 01117 \mathrm{~B}$ & Louisiana & This study & - & + \\
\hline CDR104 & $\ldots ; 01117 \mathrm{~B}$ & South Carolina & This study & - & + \\
\hline CDR218 (Fov218) & $\ldots ; 01117 \mathrm{~B}$ & North Carolina & Liu et al. 2011 & - & + \\
\hline CDR927 & $\ldots ; 01117 \mathrm{~B}$ & Texas & This study & - & + \\
\hline ATCC24907 & $\ldots ; 01117 \mathrm{C}$ & California & S. Tao & - & + \\
\hline KL11-1125 & $\ldots ; 01117 \mathrm{C}$ & Alabama & K. S. Lawrence & - & + \\
\hline CDR252 & $\ldots ; 01117 \mathrm{C}$ & Arkansas & This study & - & + \\
\hline CDR234 & $\ldots ; 01117 \mathrm{C}$ & Louisiana & This study & - & + \\
\hline CDR930 & $\ldots ; 01117 \mathrm{C}$ & Texas & This study & - & + \\
\hline ATCC16611 & $2 ; 0112$ & South Carolina & G. M. Armstrong & - & + \\
\hline KL11-304 & $\ldots ; 0112$ & Alabama & K. S. Lawrence & - & + \\
\hline KL11-402 & $\ldots ; 0112$ & Alabama & K. S. Lawrence & - & + \\
\hline CDR1006 & $\ldots ; 0112$ & Arkansas & This study & - & + \\
\hline CDR280 & $\ldots ; 0112$ & Mississippi & This study & - & + \\
\hline CDR932 & $2 ; 0112$ & Texas & This study & - & + \\
\hline CDR1131 & $\ldots ; \ldots$ & Louisiana & This study & - & + \\
\hline CBS116613 & $\ldots ; 0115$ & Ivory Coast & Abo et al. 2005 & - & + \\
\hline CBS116623 & $\ldots ; 01110$ & Ivory Coast & Abo et al. 2005 & - & + \\
\hline \multicolumn{6}{|l|}{ Race 8 lineage } \\
\hline NRRL31665 & $8 ; 01119$ & China & Skovgaard et al. 2001 & - & + \\
\hline CDR957 & $8 ; 01119$ & Alabama & This study & - & + \\
\hline CDR958 & $8 ; 01119$ & Alabama & This study & - & + \\
\hline CDR1073 & $8 ; 01119$ & Alabama & This study & - & + \\
\hline KL10-101 & $\ldots ; 01119$ & Alabama & K. S. Lawrence & - & + \\
\hline KL10-308 & ..;01119 & Alabama & K. S. Lawrence & - & + \\
\hline CDR260 & $8 ; 01119$ & Arkansas & This study & - & + \\
\hline CA-1A $(\mathrm{CA}-1)^{\mathrm{e}}$ & NP/SI & Tulare Co., CA & Kim et al. 2005 & - & + \\
\hline CA-1B $(\mathrm{CA}-1)^{\mathrm{e}}$ & 8; 01119 & Tulare Co., CA & Kim et al. 2005 & - & + \\
\hline CDR83 & ..;01119 & Georgia & This study & - & + \\
\hline CDR233 & $\ldots ; 01119$ & Louisiana & This study & - & + \\
\hline CDR203 & $\ldots ; 01119$ & South Carolina & This study & - & + \\
\hline CDR943 & $\ldots ; 01120$ & Alabama & This study & - & + \\
\hline CDR961 & $\ldots ; 01120$ & Alabama & This study & - & + \\
\hline
\end{tabular}

a Multiplex PCR with primers FovP-F, FovP-R, and FovT-R; + denotes presence of the band and - denotes absence of the band; FovT-R column indicates the 583-bp amplicon from FovP-F and FovT-R while FovP-R column indicates the 396-bp amplicon from FovP-F and FovP-R.

${ }^{\mathrm{b}} \mathrm{VCG}=$ vegetative compatibility group. $\mathrm{NP}=$ nonpathogenic in our pathogenicity assays on cotton. Isolates were obtained from diseased cotton tissues or soils in the rhizosphere of cotton. SI = heterokaryon self-incompatible.

${ }^{c}$ Lineage: phylogenetic lineage based on concatenated sequence data of translation elongation factor $(E F-1 \alpha)$, phosphate: $\mathrm{H}+\operatorname{Symporter}(P H O)$, and $\beta$-tubulin $(B T)$ genes

${ }^{\mathrm{d}}$ Original name given in the parenthesis.

e Two morphologically different isolates (A and B) were derived from the original culture in parentheses.

f This California isolate with original designation of "91-1" was given a new name "11" and placed into race 3 group by Davis et al. (2003), with S. N. Smith as one of the authors. It was later designated as CA-11 by Kim et al. (2005). However, Fernandez et al. (1994) obtained isolate "91-1" from S. N. Smith, placed it into races 1, 2, 6 group (race A), and assigned VCG0119 to this isolate. This apparent conflict raises doubt as to the identity of the isolate "91-1" used by Fernandez and the validity of the assigned vegetative compatibility group (VCG) designation. 
Table 1. (continued from preceding page)

\begin{tabular}{|c|c|c|c|c|c|}
\hline \multirow[b]{2}{*}{ Isolate } & \multirow[b]{2}{*}{ Race; VCG ${ }^{\mathbf{b}}$} & \multirow[b]{2}{*}{ Origin } & \multirow[b]{2}{*}{ Source } & \multicolumn{2}{|c|}{ Multiplex PCRa } \\
\hline & & & & FovT-R & FovP-R \\
\hline KL11-205 & $\ldots ; 01120$ & Alabama & K. S. Lawrence & - & + \\
\hline KL11-305 & $\ldots ; 01120$ & Alabama & K. S. Lawrence & - & + \\
\hline KL11-408 & $\ldots ; 01120$ & Alabama & K. S. Lawrence & - & + \\
\hline \multicolumn{6}{|l|}{ Races 4 and 7 lineage } \\
\hline ATCC16613 & $4 ; 0114$ & India & G. M. Armstrong & - & + \\
\hline BBA69519 & $4 ; 0114$ & India & Abo et al. 2005 & - & + \\
\hline BBA69520 & $4 ; 0114$ & India & Abo et al. 2005 & - & + \\
\hline BBA69521 & $4 ; 0114$ & India & Abo et al. 2005 & - & + \\
\hline NRRL31673 & $4 ; 0114$ & India & Skovgaard et al. 2001 & - & + \\
\hline NRRL31669 & $4 ; 0114$ & Unknown & Skovgaard et al. 2001 & - & + \\
\hline NRRL25433 & 7; 0114 & China & Skovgaard et al. 2001 & - & + \\
\hline NRRL31672 & 7; 0114 & China & Skovgaard et al. 2001 & - & + \\
\hline CA-9 & $4 ; 0114$ & Kings Co., CA & Davis et al. 2003; Kim et al. 2005 & + & - \\
\hline CA-12 & $4 ; 0114$ & Fresno Co., CA & Kim et al. 2005 & + & - \\
\hline CA-14A $(C A-14)^{e}$ & $4 ; 0114$ & Fresno Co., CA & Kim et al. 2005 & + & - \\
\hline CA-14B $(C A-14)^{\mathrm{e}}$ & $\ldots ;$ SI & Fresno Co., CA & Kim et al. 2005 & + & - \\
\hline CA-S9 & $4 ; 0114$ & Fresno Co., CA & Kim et al. 2005 & + & - \\
\hline MD305 & $4 ; 0114$ & Kern Co., CA & R. M. Davis & + & - \\
\hline MD306 & $4 ; 0114$ & Kern Co., CA & R. M. Davis & + & - \\
\hline MD307 & $4 ; 0114$ & Kern Co., CA & R. M. Davis & + & - \\
\hline MD308 & $4 ; 0114$ & Kern Co., CA & R. M. Davis & + & - \\
\hline MD309 & $4 ; 0114$ & Merced Co., CA & R. M. Davis & + & - \\
\hline MD310 & $4 ; 0114$ & Kern Co., CA & R. M. Davis & + & - \\
\hline MD311 & $4 ; 0114$ & Kings Co., CA & R. M. Davis & + & - \\
\hline MD312 & $4 ; 0114$ & Merced Co., CA & R. M. Davis & - & + \\
\hline MD313 & $4 ; 0114$ & Kings Co., CA & R. M. Davis & + & - \\
\hline MD314 & $4 ; 0114$ & Kern Co., CA & R. M. Davis & + & - \\
\hline MD315 & $4 ; 0114$ & Kern Co., CA & R. M. Davis & + & - \\
\hline MD316 & $4 ; 0114$ & Kings Co., CA & R. M. Davis & + & - \\
\hline MD317 & $4 ; 0114$ & Kings Co., CA & R. M. Davis & + & - \\
\hline AL-KL1 & NP & Alabama & Bennett et al. 2013 & - & + \\
\hline AL-KL11 & NP & Alabama & Bennett et al. 2013 & - & + \\
\hline MS-GL10 & NP & Mississippi & Bennett et al. 2013 & - & + \\
\hline \multicolumn{6}{|l|}{ Race 3 lineage } \\
\hline ATCC16612 & $3 ; 0113$ & Egypt & G. M. Armstrong & - & + \\
\hline CA-11 & $\ldots ;(0119)^{\mathrm{f}}$ & Tulare Co., CA & $\begin{array}{r}\text { Davis et al. 2003; Fernandez } \\
\text { et al. 1994; Kim et al. } 2005\end{array}$ & - & + \\
\hline CA-3 & NP & Tulare Co., CA & Kim et al. 2005 & - & + \\
\hline CDR1072 & $\ldots ; 01118$ & Alabama & This study & - & + \\
\hline CDR978 & ..; 01118 & Alabama & This study & - & + \\
\hline AuSeed5 & $\ldots ; 01113$ & Australia & Liu et al. 2011 & - & + \\
\hline CDR88 & NP & Florida & This study & - & + \\
\hline CDR538 & NP & Texas & This study & - & + \\
\hline AuSeed14 & $\ldots ; \ldots$ & Australia & Liu et al. 2011 & - & + \\
\hline \multicolumn{6}{|l|}{ Au lineage } \\
\hline AuK24232 & $\ldots ; 01111$ & Australia & Liu et al. 2011 & - & + \\
\hline AuK24288 & $\ldots ; 01111$ & Australia & Liu et al. 2011 & - & + \\
\hline AuK24299 & $\ldots ; 01111$ & Australia & Liu et al. 2011 & - & + \\
\hline AuK24301 & $\ldots ; 01111$ & Australia & Liu et al. 2011 & - & + \\
\hline \multicolumn{6}{|c|}{ F. oxysporum f. sp. conglutinans } \\
\hline PHW808 & $2 ; 0101$ & California & Kistler et al. 1991 & - & + \\
\hline \multicolumn{6}{|c|}{ F. oxysporum f. sp. raphani } \\
\hline PHW815 & ...;0102 & France & Kistler et al. 1991 & - & + \\
\hline \multicolumn{6}{|l|}{ F. oxysporum f. sp. pisi } \\
\hline HDV247 & $5 ; \ldots$ & Unknown & Kistler et al. 1991 & - & + \\
\hline \multicolumn{6}{|c|}{ F. oxysporum species complex $3 \mathrm{a}$} \\
\hline FOSC 3-a & $\ldots ; \ldots$ & Massachusetts & Anonymous & - & + \\
\hline \multicolumn{6}{|l|}{ F. oxysporum } \\
\hline Fo47 & $\ldots ; \ldots$ & France & Alabouvette et al. 1987 & - & + \\
\hline \multicolumn{6}{|c|}{ F. oxysporum f. sp. lycopersici } \\
\hline MN25 & $3 ; 0033$ & Florida & Anonymous & - & + \\
\hline 4287 & $2 ; 0030$ & Spain & Di Pietro and Roncero 1996 & - & + \\
\hline F. oxysporum f. sp. radi & & & & & \\
\hline CL57 & $\ldots ; 0094$ & Florida & Anonymous & - & + \\
\hline
\end{tabular}


Table 1. (continued from preceding page)

\begin{tabular}{|c|c|c|c|c|c|}
\hline \multirow[b]{2}{*}{ Isolate } & \multirow[b]{2}{*}{ Race; $V_{C G}{ }^{b}$} & \multirow[b]{2}{*}{ Origin } & \multirow[b]{2}{*}{ Source } & \multicolumn{2}{|c|}{ Multiplex PCRa } \\
\hline & & & & FovT-R & FovP-R \\
\hline \multicolumn{6}{|c|}{ F. oxysporum f. sp. melonis } \\
\hline NRRL26406 & $\ldots ; \ldots$ & Mexico & Ma et al. 2014 & - & + \\
\hline \multicolumn{6}{|c|}{ F. oxysporum f. sp. cubense } \\
\hline II5 & $4 ; 01213$ & Indonesia & Anonymous & - & + \\
\hline \multicolumn{6}{|l|}{ F. verticillioides } \\
\hline 7600 & $\ldots ; \ldots$ & California & Anonymous & - & + \\
\hline \multicolumn{6}{|l|}{ F. graminearum } \\
\hline PH-1 & $\ldots ; \ldots$ & Michigan & Anonymous & - & - \\
\hline \multicolumn{6}{|l|}{ F. semitectum } \\
\hline CDRFsGA2 & $\ldots ; \ldots$ & Georgia & This study & - & - \\
\hline \multicolumn{6}{|l|}{ F. equiseti } \\
\hline CDRFe1 & $\ldots ; \ldots$ & Texas & This study & - & - \\
\hline \multicolumn{6}{|c|}{ F. solani $\mathrm{f}$. sp. pisi } \\
\hline $77-13-4$ & $\ldots ; \ldots$ & $\begin{array}{l}\text { Northeastern } \\
\text { United States }\end{array}$ & Coleman et al. 2009 & - & - \\
\hline \multicolumn{6}{|c|}{ Verticillium dahlia } \\
\hline V-76 & $\ldots ; 1 \mathrm{~A}$ & Mexico & Puhalla and Hummel 1983 & - & - \\
\hline \multicolumn{6}{|c|}{ Thielaviopsis basicola } \\
\hline CDRTb1 & $\ldots ; \ldots$ & Texas & This study & - & - \\
\hline \multicolumn{6}{|c|}{ Chaetomium funicola } \\
\hline CDRCf1 & $\ldots ; \ldots$ & Texas & This study & - & - \\
\hline \multicolumn{6}{|l|}{ Phoma exigua } \\
\hline CDRPe1 & $\ldots ; \ldots$ & Texas & This study & - & - \\
\hline \multicolumn{6}{|c|}{ Aspergillus tubingensis } \\
\hline CDRAt01 & $\ldots ; \ldots$ & Louisiana & Crutcher et al. 2014 & - & - \\
\hline \multicolumn{6}{|c|}{ Penicillium chrysogenum } \\
\hline CDRPc1 & $\ldots ; \ldots$ & Texas & F. K. Crutcher & - & - \\
\hline \multicolumn{6}{|c|}{ Tricoderma virens } \\
\hline Gv29-8 & $\ldots ; \ldots$ & Texas & Dave et al. 1994 & - & - \\
\hline \multicolumn{6}{|c|}{ Talaromyces verruculosus } \\
\hline CDRTv1 & $\ldots ; \ldots$ & Texas & F. K. Crutcher & - & - \\
\hline
\end{tabular}

but these isolates were weak pathogens and were distinguished from race 4 by DNA sequences (Bennett et al. 2013) or vegetative compatibility (this study).

Since 2001, Cal race 4 isolates have been detected in increasing numbers of fields in California but, currently, are confined to that state. With inoculum level buildup, even tolerant varieties can sustain severe yield loss. Lack of resistant cultivars and persistence of the fungus in the field for decades, even in the absence of the cotton host, has increased concern about this race spreading throughout the U.S. Cotton Belt. Moreover, the presence of many possible mechanisms for fungal spore dispersal, including seedborne dissemination and soil and plant debris movement, make containment of the organism problematic (Davis et al. 2006; Liu et al. 2011; Smith and Snyder 1975). Therefore, a reliable detection method is imperative for early identification of infested fields and seed lots in order to prevent further movement of Cal race 4.

A primer pair designed to be race 4-specific has been developed to detect the presence of race 4 in cotton by polymerase chain reaction (PCR) (Yang et al. 2006) and a commercial race 4 detection kit has been developed with modified primers for use in an isothermal recombinase polymerase amplification reaction based on the same primer pair (Doan et al. 2014). However, both the PCR and the commercial kit showed positive reactions on the India race 3 and China race 7 reference isolates (Crutcher et al. 2016; Yang 2006). In this report, we describe a unique Tfol transposon insertion in the $P H O$ gene in the $\mathrm{Cal}$ race 4 isolates. This insertion event was not present in any other known races or genotypes of $F$. oxysporum f. sp. vasinfectum isolates, and was used for the development of a Cal race 4-specific detection method using a multiplex PCR platform. The method was validated with a panel of $F$. oxysporum $\mathrm{f}$. sp. vasinfectum isolates representing all known races and sequence types. These isolates were selected from initial VCG analysis of a large collection of $F$. oxysporum $\mathrm{f}$. sp. vasinfectum isolates followed by DNA sequence analysis of several isolates within each VCG.

\section{Materials and Methods}

Fungal isolates. Fungal isolates used in this study are summarized in Table 1. Isolates were selected after initial screening with VCG analysis of $F$. oxysporum $\mathrm{f}$. sp. vasinfectum isolates from our and others fungal collections comprising more than 2,000 isolates. Within each VCG, several isolates (preferably from different geographic locations) were sequenced to identify all the possible genotypes for inclusion in the test panel. Thus, isolates represent all the known genetic diversity (17 VCG and 3 unnamed single-member VCG) within $F$. oxysporum $\mathrm{f}$. sp. vasinfectum and geographic locations where cotton is grown in the United States. All the known race reference isolates and biotypes collected from major cotton-growing areas around the world were included. Each of the four Cal race 4 isolates with "CA" designations were collected from different fields in Fresno and Kings Counties of California's San Joaquin Valley prior to 2003 (Davis et al. 2003). Thirteen Cal race 4 isolates with "MD" designations were collected in 2014 from Kern, Kings, and Merced Counties in the San Joaquin Valley and were kindly provided by Dr. R. M. Davis (University of California, Davis). Most of California's cotton is grown in Fresno, Kings, and Kern Counties. Additional isolates representing other forma speciales of the $F$. oxysporum species complex, other distantly related Fusarium spp., as well as cottonassociated and soil-inhabiting fungal species also were part of this study. Pathogenicity of the cotton F. oxysporum isolates was evaluated by us or by the isolate contributors. All isolates were found to be pathogenic, unless otherwise noted, via stem puncture or soil infestation assays with or without root-knot nematodes (data not shown).

Isolate stocks were grown on $0.2 \times$ potato dextrose agar (PDA; Difco Laboratories, Detroit) plates amended with tetracycline (50 mg/liter) and chloramphenicol (100 mg/liter). After a round of 
single-spore isolation, cultures were grown on $0.2 \times$ PDA plates for 7 days at $24^{\circ} \mathrm{C}$. Glycerol stocks ( $30 \%$ glycerol [ $\left.\mathrm{vol} / \mathrm{vol}\right]$ ) for each culture were made and stored at $-80^{\circ} \mathrm{C}$.

Infection assay. Cotton seed (G. hirsutum L. 'Coker 312') were germinated by chipping the seed near the chalaza, wrapping them in filter paper, and placing them in a cup containing $10 \mathrm{ml}$ of water. The cup was placed in a $30^{\circ} \mathrm{C}$ incubator for $24 \mathrm{~h}$, then transferred to a $16^{\circ} \mathrm{C}$ room for an additional $24 \mathrm{~h}$. Seedlings with a radicle length of about 1.3 to $2.5 \mathrm{~cm}$ were planted in plastic cups containing sterile $3: 1$ sand-loam (vol/vol, $500 \mathrm{ml}$ total) with a core of sand-loam $(50 \mathrm{~g})$ mixed with cotton root powder $(1.5 \mathrm{~g})$. Pots were then inoculated at five locations, each with $1 \mathrm{ml}\left(1 \times 10^{6}\right)$ of $F$. oxysporum f. sp. vasinfectum CA-9 fungal spores (or water as negative control) in a 2 -cm radius from the planted seedling. Pots were placed and maintained in a growth chamber with a 13-h day $\left(6,000\right.$ lux) at 23 and $18^{\circ} \mathrm{C}$ (day and night, respectively) for 3 or 6 weeks. Disease severity was then visually evaluated on a rating scale of 0 to 4 , where $0=$ no symptoms; $1=$ growth slightly suppressed or mild yellowing compared with healthy control with no more than 2 leaves wilted; 2 = severe yellowing and growth suppressed with more than 2 leaves wilted but at least $25 \%$ of leaves unaffected; $3=$ all leaves showed wilting but at least one leaf not completely wilted (epinasty only, with no chlorotic mottling) and the top terminal of plant still upright; and $4=$ all leaves completely wilted, plant bent at the top or dead. Cotton stems were cut about $1.5 \mathrm{~cm}$ in length just above the soil level from diseased and healthy (mock-inoculated) plants, surface sterilized, rinsed with sterile water, and flash frozen in liquid nitrogen for DNA extraction. The experiments were repeated.

Vegetative complementation. Vegetative compatibility of the isolates was tested according to Puhalla (1985) and Correll et al. (1987). Single-spore isolates were grown on freshly prepared potato sucrose agar (Puhalla 1985) containing 2\% sodium chlorate (PSAC). Fast-growing sectors or dense circular areas within colonies were subcultured to new PSAC. After 3 to 4 days, hyphal fronts from subcultures were transferred to nitrate medium. Nitrate-nonutilizing (nit) mutants were identified using the media of Puhalla and Spieth (1983). Complementation among nit-1, nit-3, and nit-M mutants was first tested within an isolate to confirm that it was heterokaryon self-compatible and then among confirmed isolates to determine relationships.

DNA extraction. Fungal tissue was grown in liquid yeast extract peptone dextrose medium and incubated at $24^{\circ} \mathrm{C}$ for 5 days without shaking. Tissue was harvested on a sterile filter paper (Whatman, Maidstone, England) by vacuuming out the liquid and immediately

Table 2. DNA primers used in this study

\begin{tabular}{|c|c|c|}
\hline Name $^{\mathbf{a}}$ & Sequence $\left(5^{\prime}-3^{\prime}\right)$ & Reference \\
\hline \multicolumn{3}{|l|}{$\overline{E F}-1 \alpha$} \\
\hline EF-1A & CACCTTAACGTCGTCGTCATC & Liu et al. 2011 \\
\hline EF1885R & CGAGTGCTCATGCCAACAT & This study \\
\hline \multicolumn{3}{|l|}{$\mathrm{PHO}$} \\
\hline PHO48F & TGCCTTCCACAACTTTCACA & This study \\
\hline PHO2034R & TCTCAACCAAATCAAGGAATGTT & This study \\
\hline \multicolumn{3}{|l|}{$\beta$-Tubulin (BT) } \\
\hline BT-100F & CCGTCAAAGCTAGGTCTACTTCA & This study \\
\hline BT1828R & TGGAATTTTATTCGGCTCAT & This study \\
\hline \multicolumn{3}{|c|}{$\mathrm{PHO}$ genome walk } \\
\hline PHO-wR & $\begin{array}{l}\text { TCGCCTTGAGTGTACATGAACT } \\
\text { TACTCG }\end{array}$ & This study \\
\hline PHO-w2R & $\begin{array}{l}\text { AAGAAAGGGGATAATCACCACC } \\
\text { AATACC }\end{array}$ & This study \\
\hline \multicolumn{3}{|c|}{ PHO-Tfol detection } \\
\hline FovP-F & GGCCGATATTGTCGGTCGTA & This study \\
\hline FovP-R & CTCCAGTGCAGTGCTTGGTA & This study \\
\hline FovT-R & ATCTGTCTTTCGTCGGCAAT & This study \\
\hline \multicolumn{3}{|c|}{$\begin{array}{l}\text { Cellulose } \\
\text { synthase A1 }\end{array}$} \\
\hline CelA1-F & GGATCTGCACCCATCAATCT & Xin et al. 2003 \\
\hline CelA1-R & GCAAAGAGATGGGCTGAAAC & Xin et al. 2003 \\
\hline
\end{tabular}

flash freezing in liquid nitrogen. Fungal DNA was isolated by a modified minipreparation procedure (Woloshuk et al. 1989) and resuspended in sterile distilled water.

For DNA extraction from both the infected and healthy plant tissues, a procedure of Li et al. (2001) was utilized, with the following modifications: the extraction buffer was not used; instead, $0.03 \% \beta$-mercaptoethanol ( $\mathrm{vol} / \mathrm{vol}$ ) was added to the lysis buffer and this was then added to the frozen ground plant tissue. Additionally, all centrifugation steps were reduced to $10 \mathrm{~min}$. DNA was resuspended in distilled water.

DNA concentrations were determined via NanoDrop (Thermo Scientific, Wilmington, DE) and integrity was analyzed by gel electrophoresis. Working DNA dilutions $(50 \mathrm{ng} / \mu \mathrm{l})$ were made and used throughout this study unless specified.

Sequencing and Phylogenetic analysis. Portions of three nuclear genes - translation elongation factor $(E F-1 \alpha)$, phosphate: $\mathrm{H}^{+}$symporter $(P H O)$, and $\beta$-tubulin $(B T)$-were amplified using primers listed in Table 2. $\mathrm{PHO}$ with a Tfol insertion was amplified in four overlapping fragments with primer pairs PHO48F and Tfo1451R, FovP-F and Tfo1919R, Tfo1730F and FovP-R, and Tfo2773F and PHO2034R (Table 1; Supplementary Table S1). Amplification was carried out in $100-\mu l$ reaction mixtures containing $100 \mathrm{ng}$ of template DNA, $1.5 \mathrm{mM} \mathrm{MgCl}_{2}, 200 \mu \mathrm{M} \mathrm{dNTP}, 200 \mathrm{nM}$ primers, and $2.5 \mathrm{U}$ of GoTaq DNA polymerase in 1× GoTaq Flexi Buffer (Promega Corp., Madison, WI) and performed in an Eppendorf Mastercycler (Eppendorf, Westbury, NY) with the following program: initial denaturing at $94^{\circ} \mathrm{C}$ for $2 \mathrm{~min} ; 35$ cycles of denaturing at $94^{\circ} \mathrm{C}$ for $30 \mathrm{~s}$, annealing at $58^{\circ} \mathrm{C}$ for $30 \mathrm{~s}$, and extension at $72^{\circ} \mathrm{C}$ for $2 \mathrm{~min}$; and final extension at $72^{\circ} \mathrm{C}$ for $5 \mathrm{~min}$. PCR products were purified using the QIAquick PCR Purification Kit (Qiagen, Valencia, CA) according to the manufacturer's instructions. The same primers used for amplification and additional internal primers listed in Supplementary Table S1 were used to sequence the purified amplicons using the BigDye Terminator kit (v3.1; Perkin-Elmer, Boston) in an Eppendorf Mastercycler with the following cycling parameters: initial denaturation at $96^{\circ} \mathrm{C}$ for $2 \mathrm{~min} ; 40$ cycles of denaturation at $96^{\circ} \mathrm{C}$ for $15 \mathrm{~s}$ and annealing at $55^{\circ} \mathrm{C}$ for $15 \mathrm{~s}$; and extension at $60^{\circ} \mathrm{C}$ for $4 \mathrm{~min}$. Sequencing reaction mixtures were purified using Micro Bio-Spin P-30 spin columns (Bio-Rad, Hercules, CA) and analyzed on an ABI PRISM 3100 Genetic Analyzer (Applied Biosystems, Foster City, CA) at the Texas A\&M University Gene Technology Laboratory. Sequences were edited and aligned using Sequencher (version 4.8; Gene Codes, Ann Arbor, MI), and deposited in GenBank with the corresponding accession numbers listed in Supplementary Table S2.

DNA sequences were aligned using the Clustal W program (Thompson et al. 1994) and adjusted manually. Phylogenetic analyses were performed using the neighbor-joining method (Saitou and Nei 1987) implemented in the phylogenetic analysis program of MEGA 6.0 (Tamura et al. 2007) based on concatenated sequences of $E F-1 \alpha, P H O$, and $B T$ genes of the isolates investigated in this study and isolates representing known genotypes. The Tfol insertion sequence was coded as a single character in the $\mathrm{PHO}$ sequence. Sequences were compared with those of $F$. oxysporum strains and $F$. verticillioides strain 7600 (NCBI genome accession numbers: GCA_000149555.1, GCA_000149955.2, GCA_000259975.2, GCA_000260075.2, GCA_000260155.3, GCA_000260195.2, GCA_000260215.2, GCA_000260235.2, GCA_000260495.2, GCA_000271705.2, GCA_000271745.2). Kimura's two-parameter distance option and pairwise deletion of gap option were used. Statistical support for the derived tree was obtained by running 1,000 bootstrap replicates.

Genome Walking. Insertion sequence of the Tfol within the $\mathrm{PHO}$ gene was captured using a Genome Walker kit (Clontech Laboratories, Mountain View, CA) following the manufacturer's protocols. Primers PHO-wR and PHO-w2R (Table 2) were used with AP1 and AP2 primers, respectively, to amplify the five libraries of the kit. The amplified fragments were resolved, purified, and sequenced as described above.

Detection of $\mathrm{Tfo} 1$ insertion in $\mathrm{PHO}$, sequence analysis, and amplification. $\mathrm{PHO}$ nucleotide sequences were aligned using Sequencher 4.8 software. Primers were designed manually and in silico based on CA-9 strain sequences and other $\mathrm{PHO}$-sequenced 
fragments from diverse $F$. oxysporum f. sp. vasinfectum isolates using the Primer-BLAST web-based platform (Ye et al. 2012). For amplification, the same GoTaq PCR mix conditions described above were used, with the exception of the addition of $0.1 \mu \mathrm{M}$ each FovP-F, FovP-R, and FovT-R primer and 50 ng of DNA in a $25-\mu 1$ reaction, unless otherwise specified. Negative controls without DNA template were included in every experiment to test for contamination or nonspecific amplification. After PCR, amplification products were resolved in an ethidium bromide prestained $1 \%$ agarose-Tris-acetate-EDTA gel at $6 \mathrm{~V} / \mathrm{cm}$ for $35 \mathrm{~min}$ and photographed. To check the suitability of the plant sample's total DNA, primers CelA1-F and CelA1-R were used to amplify a 401-bp product of cotton's cellulose synthase A1 gene.

\section{Results}

A Tfo1 transposable element resides in the $\mathrm{PHO}$ gene of $F$. oxysporum f. sp. vasinfectum Cal race 4 isolates. Attempts to amplify the $\mathrm{PHO}$ gene of $\mathrm{Cal}$ race 4 isolates failed to yield an amplicon using Taq polymerase if the primer pair surrounded base position 462. Amplicons for both the upstream region and the downstream region around position 462 had sequences identical to the corresponding $\mathrm{PHO}$ sequences of the race 4 reference isolate, indicating the presence of either a large insertion or a translocation in the $\mathrm{Cal}$ race 4 isolates. Genome walking upstream from the downstream side of position 462 generated a sequence about $1 \mathrm{~kb}$ in size that was more than $99 \%$ identical to that of the $F$. oxysporum transposon $T f o 1$ (Okuda et al. 1998). Tfol-based primers along with $\mathrm{PHO}$-based primers (Table 2) enabled sequencing of the complete Tfol insert and the surrounding $\mathrm{PHO}$ gene sequences. The insertion was $2,763 \mathrm{bp}$ long and was located $463 \mathrm{bp}$ upstream from the $P H O$ start codon. None of other F. oxysporum f. sp. vasinfectum isolates sequenced, including the reference isolates India race 4 and China race 7, had the insertion at this position (Fig. 1). Using the junction sequence of $\mathrm{PHO}$ and $\mathrm{Tfol}, \mathrm{PHO}$ sequence-specific primers upstream and downstream of the Tfol insertion (FovP-F and FovP-R; Fig. 2A) as well as one within the $T f o 1$ open reading frame (FovT-R) were designed and tested (Table 2). Primer pair FovP-F and FovP-R was based on the conserved sequences of $F$. oxysporum isolates and produced a 396-bp amplicon. Primer combination FovP-F and FovT-R produced a 583-bp amplicon (Fig. 2A). The 396-bp amplicon is only produced when a $T f o l$ insertion is not present in $P H O$, whereas a Tfol insertion in $\mathrm{PHO}$ produces a 583-bp band. Based on this data, a multiplex PCR assay where the three primers were included was designed. No cross-reactivity was observed among primer pairs and only one band was produced per reaction on all tested $F$. oxysporum isolates.

Assessment of genetic diversity within $F$. oxysporum f. sp. vasinfectum and selection of a panel of $F$. oxysporum $f$. sp. vasinfectum isolates to validate Cal race 4-specific detection method. Genetic diversity within $F$. oxysporum $\mathrm{f}$. sp. vasinfectum was assessed by VCG and sequence analysis. In all, $97 F$. oxysporum isolates from cotton were selected after initial screening with VCG analysis of more than 2,000 isolates from our and other fungal collections, followed by sequencing several isolates within each VCG to represent all the known genetic diversity within $F$. oxysporum $\mathrm{f}$. sp. vasinfectum (Table 1). Genetic relationships among different VCG were evaluated by phylogenetic analysis based on the $E F-1 \alpha, P H O$, and $B T$ genes comprising more than $5.6 \mathrm{~kb}$ of genomic sequence (Fig. 3). In all, $17 \mathrm{VCG}$, a few heterokaryon self-incompatible isolates, a few single-member VCG, and 23 sequence types in five lineage groups were observed within $F$. oxysporum from cotton (Fig. 3; Table 1). In most cases, a single VCG corresponded to a single sequence type, except one sequence type corresponded to three VCG (VCG0116, -01115, and -01116).

Reference isolates of $F$. oxysporum $\mathrm{f}$. sp. vasinfectum races $1,2,3$, 4, 6, 7, and 8; Australian VCG01111; and 11 additional VCG, as well as sequenced isolates of other $F$. oxysporum formae speciales and other Fusarium spp. (Broad Institute), were used to test specificity of the Tfol insertion. Isolates representing other fungal species commonly associated with cotton were also tested. In total, 120 fungal strains were tested to validate the specificity of detection method (Table 1).

Multiplex PCR system differentiates between $F$. oxysporum f. sp. vasinfectum Cal race 4 isolates and other $F$. oxysporum f. sp. vasinfectum and fungal species. Twenty-four $F$. oxysporum $\mathrm{f}$. sp. vasinfectum isolates from California cotton fields, consisting of

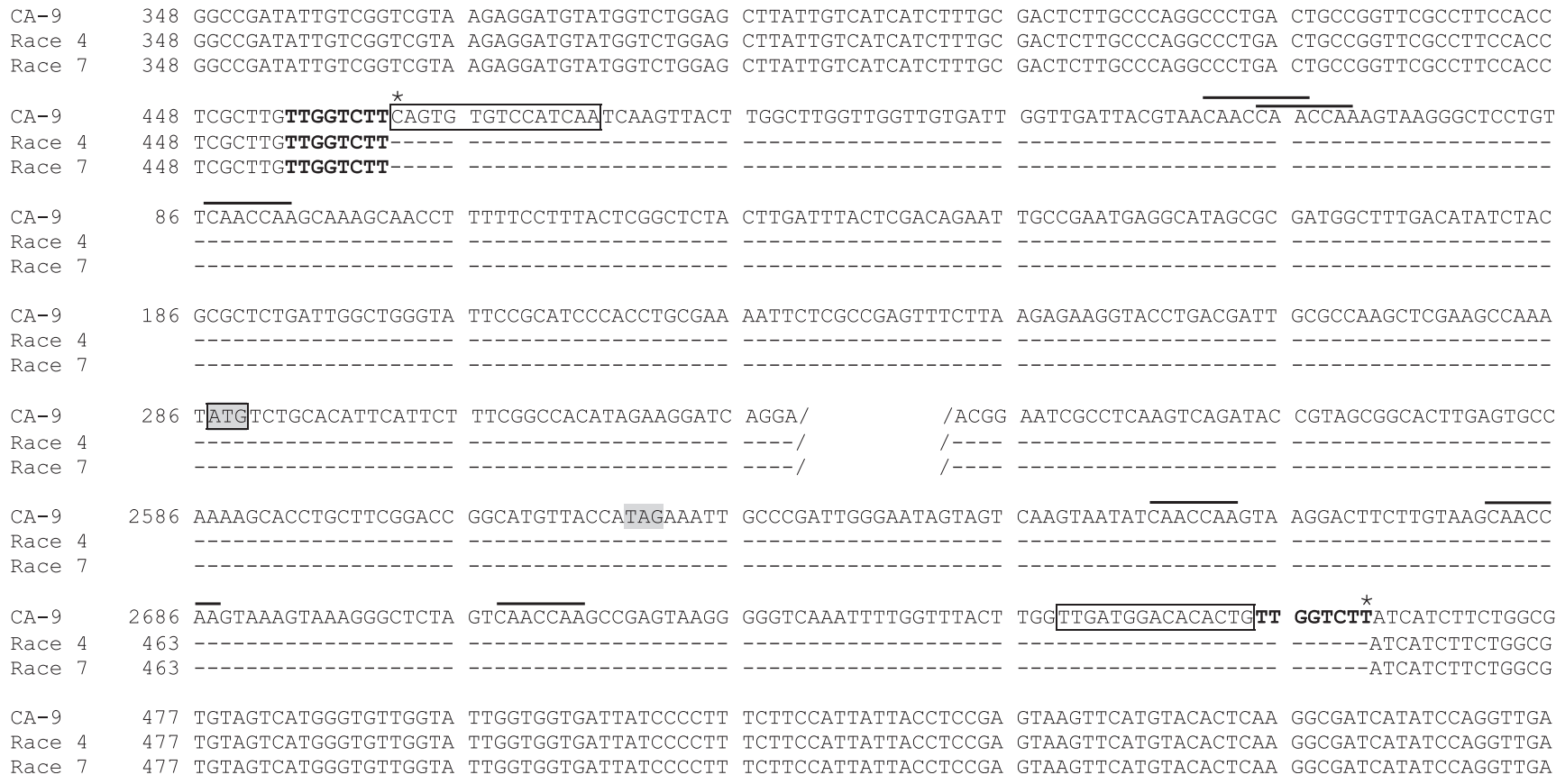

Fig. 1. Sequence alignment of the phosphate: $\mathrm{H}^{+}$symporter gene $(P H O)$ of Fusarium oxysporum f. sp. vasinfectum isolates. Isolate $\mathrm{CA}-9$ contains a Tfo1 transposon insertion not found in reference isolates of race 4 from India (ATCC16613) or race 7 from China (F. oxysporum f. sp. vasinfectum NRRL25433). Boxed in is the conserved $h A T$ transposon family's 15-bp terminal inverted repeat sequence while the 8-bp target site duplication (TSD) motif is in bold. Overlined nucleotides represent characteristic subterminal repeat regions. Reading frame of Tfo1 is marked by the boxed-in and grayed-out start codon while the stop codon is grayed out. Asterisks $\left(^{*}\right)$ denote the beginning, recalibrated as base 1, and end of the Tfo1 insertion, including the 8-bp 3' TSD generated by the transposon. Part (2.2 kb) of the Tfo1 sequences have been omitted in the figure for spacing purposes. 
races $1,3,4$, and 8 , were assayed. Of these, 16 of 17 isolates previously identified as $\mathrm{Cal}$ race 4 produced the 583-bp amplicon characteristic of the PHO-Tfol insertion (Fig. 2C; Table 1); isolate MD312 produced a 396-bp band. Isolate MD312 had moderate virulence in soil-infestation assays compared with the 16 isolates with

A

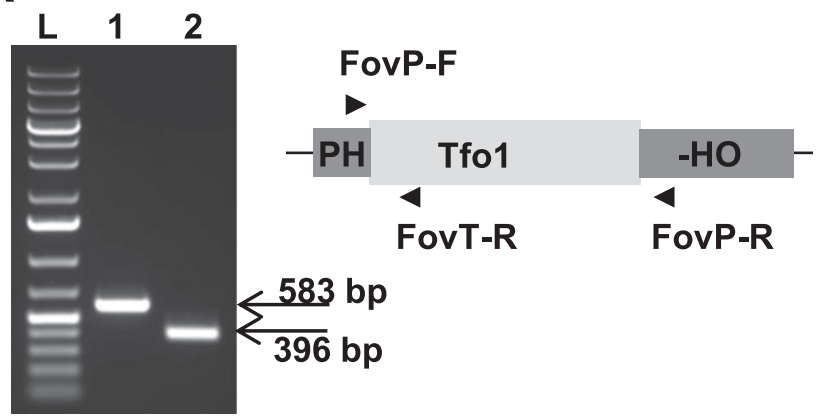

B

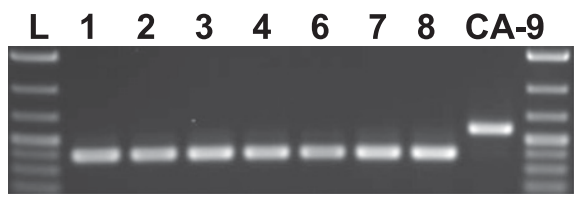

C

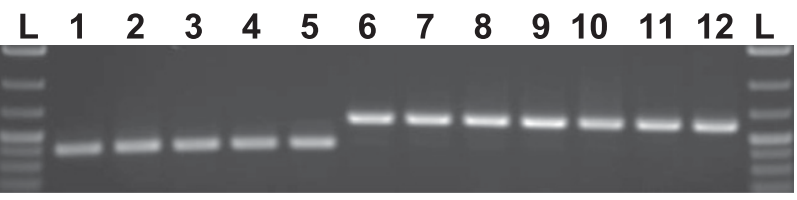

D

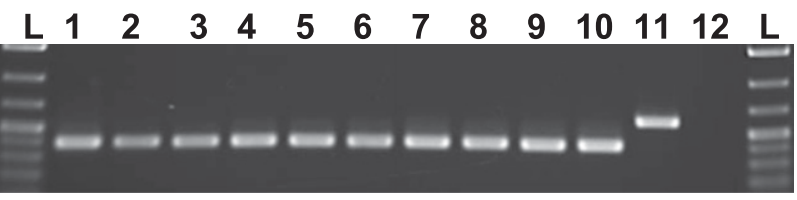

Fig. 2. Detection of Cal race 4 isolates of Fusarium oxysporum f. sp. vasinfectum using multiplex polymerase chain reaction (PCR). Cal race 4 strains produce a 583-bp amplicon while other $F$. oxysporum f. $\mathrm{sp}$. vasinfectum isolates produce a 396-bp band based on Tfo1 insertion status of the phosphate: $\mathrm{H}^{+}$symporter $(\mathrm{PHO})$ gene. A, Left panel: detection of Tfo1 insertion in the PHO gene, where a 583-bp band is produced when an insertion is present (lane 1 , Cal race 4 isolate CA-14) and a 396-bp band is produced when an intact PHO is present (lane 2, India race 4 reference isolate ATCC16613). Right panel: target location of PCR primers used in the multiplex. B, F. oxysporum f. sp. vasinfectum race isolates (left to right: race 1, ATCC16421; race 2, ATCC16611; race 3, ATTC16612; race 4, ATTC16613; race 6, ATTC36198; race 7, NRRL25433; and race 8, NRRL31665; Cal race 4, CA-9), analyzed with the multiplex system. C, Detection of PHO-TfO1 in California F. oxysporum f. sp. vasinfectum isolates representing diverse races: lane 1 (CA-1A) is an isolate with a race 8 sequence type; lane $2(C A-1 B)$ is a race 8 isolate; lanes 3 and 5 (CA-3 and CA-11, respectively) are isolates with DNA sequences similar to the race 3 reference isolate; lane 4 (CA-10) is a VCG01117A isolate with DNA sequences similar to races 6 reference isolate; and lanes 6 to 12 (CA-12, CA-14A, CA-S9, MD305, MD306, MD307, and CA-9, respectively) are Cal race 4 isolates. $D, F$. oxysporum isolates of diverse sequence types and vegetative compatibility groups (VCG) collected outside California: lanes 1, 3, 4, and 8 (CDR88, CDR538, CDR978, and Auseed5, respectively) are isolates with DNA sequences similar to those of the race 3 reference isolate; lanes 6, 7, and 10 (AL-KL11, MS-GL10, and AL-KL1, respectively) are isolates with a translation elongation factor $1 \alpha$ DNA sequence, within limited stretches examined at an earlier study, identical to those of race 4 and which have been called "race 4-like" isolates; lanes 2 and 9 (CDR238 and Fov218, respectively) are race 1, 2, 6 lineage isolates; lane 5 (CDR943) is an isolate with DNA sequences similar to those of race 8 reference isolate; lane 11 $(\mathrm{CA}-9)$ is a Cal race 4 isolate; lane 12 is a negative control without a DNA template; and lane $L$ is a $1 \mathrm{~kb}$-plus DNA ladder. the PHO-Tfol insertion, which displayed a range of virulence. The remaining seven isolates of diverse race, sequence type, and VCG from California produced the 396-bp amplicon, denoting the lack of the Tfol insertion. Similarly, $71 \mathrm{~F}$. oxysporum isolates from cotton, including race 4 and 7 isolates, from fields outside of California produced only the 396-bp amplicon (Fig. 2D; Table 1). Moreover, all isolates from the seven named $F$. oxysporum $\mathrm{f}$. sp. vasinfectum races (Fig. 2B; Table 1), seven nonpathogenic $F$. oxysporum isolates recovered from diseased cotton tissues or soils in the rhizosphere of cotton, eight isolates from seven other $F$. oxysporum formae speciales, one clinical isolate, and one biocontrol isolate of $F$. oxysporum produced only the 396-bp band (Table 1). Additionally, when assaying other Fusarium spp. (F. verticillioides 7600 , $F$. graminearum $\mathrm{PH}-1$, and $F$. solani) and other common soilborne fungal species, only $F$. verticillioides produced the 396-bp band and was negative for the $T f o l$ insertion band. No product was amplified from all other species when our primers were tested in the multiplex or two-primer PCR system (Table 1).

In addition to specificity, the sensitivity of the detection system was evaluated by assaying Cal race 4 isolate CA- 9 and the race 4 reference isolate DNA. Testing concentrations ranging from $2 \mathrm{ng} / \mu \mathrm{l}$ to $600 \mathrm{fg} / \mu \mathrm{l}$ revealed a detection limit of $5 \mathrm{pg} / \mu \mathrm{l}$ for the $T f o 1$ insert and $40 \mathrm{pg} / \mu \mathrm{l}$ for the undisrupted $P H O$, respectively, for the two isolates.

Diagnostic system provides reliable detection of Cal race 4 isolates in planta. The multiplex system was tested in planta with total DNA (fungal and plant DNA) extracted from infected and mockinoculated plants 6 weeks after inoculation with CA-9 (Fig. 4A). The system was able to detect and amplify the 583-bp Tfol insertion event in the extracted DNA at concentrations ranging from 800 to $12.5 \mathrm{ng}$ of total DNA per $25-\mu \mathrm{l}$ reaction medium prepared from plants given a disease score of 2 , or down to $25 \mathrm{ng}$ from plants given a disease score of 1 (Fig. 4B). In order to determine the detection limits with fungal DNA in the presence of a large excess of plant total DNA, infected plant total DNA was mixed with uninfected plant DNA in 1:0, 1:1, 1:9, 1:24, 1:49, and 1:99 ratios. These mixed DNA samples were then used as template at a concentration of $50 \mathrm{ng}$ of DNA per $25-\mu l$ PCR assay. The system was able to amplify the 583-bp band down to a 1:49 dilution for infected plants with a disease score of 2. For less severely infected plants, with a disease score of 1 , the band was discernible when the sample was diluted in a 1:9 ratio (Fig. 4C). Uninfected plant DNA did not amplify a band when tested with the multiplex system (Fig. 4B). The suitability of the plant sample's total DNA for PCR was independently confirmed using primers CelA1-F and CelA1-R targeting cotton's cellulose synthase A1 gene (Fig. 4D).

Cotton plants started to show symptoms about 3 weeks after inoculation with Cal race 4 isolate CA-9 (Fig. 4E). Initial symptoms often were severe but some plants did partially recover. Colonization by the pathogen in the 3-week-old infected plants with a disease severity rating of 3 was much less extensive than in the 6-week-old infected plants with a disease severity rating of 2 (Fig. 4E versus A), which was also reflected in the weaker $P H O-T f o l$ detection band intensity in the former plant (Fig. 4F versus B). CA- 9 can also be detected in plants showing no external symptoms (Fig. 4E and F).

\section{Discussion}

We have serendipitously discovered that an Ac-like Tfol transposon is present within the $P H O$ gene of Cal race 4 isolate CA-9. Further screening revealed that this insertion is present in 15 of 16 other F. oxysporum $\mathrm{f}$. sp. vasinfectum $\mathrm{Cal}$ race 4 isolates tested (Table 1). The exception is the California isolate MD312, which shares identical sequences with the India race 4 reference isolate and a China race 7 isolate in the three sequenced nuclear genes. The other $16 \mathrm{Cal}$ race 4 isolates also share identical sequences with these isolates, except for the Tfol insertion in the $\mathrm{PHO}$ gene. All four of the India race 4 reference isolates, all Cal race 4 isolates (including MD312), and the two China race 7 isolates belonged to VCG0114 (Table 1). Thus, all of these isolates were apparently derived from a single clonal lineage yet display distinct differences in pathogenicity. 
The $P H O$ gene is involved in the transport of inorganic phosphate across plasma membranes (Persson et al. 1999). Fragments of this gene have been widely used for Fusarium phylogenetic analyses (Kim et al. 2005; Liu et al. 2011; Skovgaard et al. 2001) as well as a species-specific marker because of its high degree of polymorphism (Persson et al. 1999; Stakheev et al. 2013). Previous studies analyzing the $\mathrm{PHO}$ gene sequence of $\mathrm{CA}-9$ and other $\mathrm{Cal}$ Race 4 isolates were not able to detect this insertion due to the preferred $\mathrm{PHO}$ fragment used for phylogenetic studies. Kim et al. (2005) amplified a 975-bp fragment of $P H O$ and then used 513 bp of this fragment for their phylogenetic study. Their amplified fragment is located at base 466 of the $\mathrm{PHO}$ gene, just 4 bases downstream of the $3^{\prime}$ target site duplication of the Tfol insertion reported in this study.

The Tfol insertional event in $P H O$ of Cal race 4 was not found in any of the other $F$. oxysporum $\mathrm{f}$. sp. vasinfectum isolates tested, which belong to 22 other sequence types and 23 other VCG (Fig. 3)

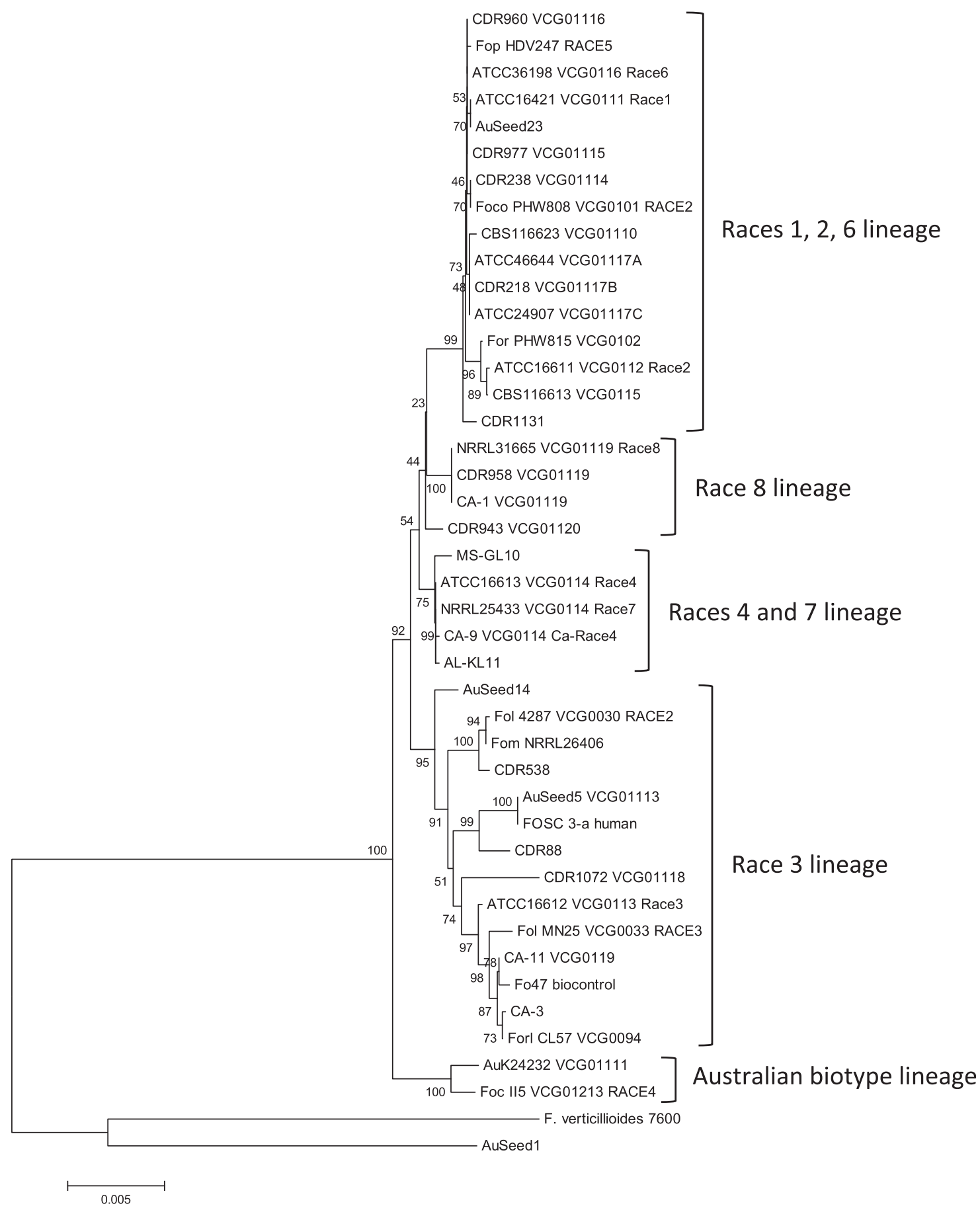

Fig. 3. Phylogenetic tree of diverse Fusarium oxysporum isolates. Tree constructed by the neighbor-joining method based on the concatenated sequences of translation elongation factor $1 \alpha$ (1,831-bp aligned length), phosphate: $\mathrm{H}^{+}$symporter (PHO; 1,945-bp aligned length), and $\beta$-tubulin (1,892-bp aligned length) from $F$. oxysporum f. sp. vasinfectum isolates representing known races, most vegetative compatibility groups (VCG), and sequence types. The Tfo1 insertion sequence was coded as a single character in the $P H O$ sequence. Sequences of a number of $F$. oxysporum formae speciales (pisi HDV247, conglutinans PHW808, raphani PHW815, vasinfectum NRRL25443, lycopersici 4287, melonis NRRL26406, Iycopersici MN25, radicis-lycopersici CL57, and cubense II5), a clinical F. oxysporum isolate (FOSC 3-a), an F. oxysporum biocontrol agent (Fo47), and an $F$. verticillioides isolate (Fv7600), whose genome sequences are available from Broad Institute, were also included in the analysis as references. Sequences of Fusarium sp. isolate AuSeed1 (Liu et al. 2011) was also included to root the tree. Distances were determined by Kimura's two-parameter model. Bootstrap frequencies from 1,000 replications are noted next to the branches. The scale is equivalent to 5 nucleotide substitutions per 1,000 bp. 
representing all the known genetic diversity within $F$. oxysporum f. sp. vasinfectum. Moreover, no insertion at this locus was found among any of the $11 F$. oxysporum genomes, or the $F$. verticillioides and $F$. graminearum genomes available from Broad Institute. Therefore, this unique insertion event provides a platform to develop a racespecific detection method for $F$. oxysporum $\mathrm{f}$. sp. vasinfectum $\mathrm{Cal}$ race 4 isolates. The detection method described herein relies on three sequence-specific primers designed to simultaneously detect $\mathrm{Cal}$ race 4 and other $F$. oxysporum f. sp. vasinfectum by amplifying the $\mathrm{PHO}$-Tfol junction (FovP-F and FovT-R, 583-bp amplicon) or a fragment of the $F$. oxysporum $\mathrm{PHO}$ gene (FovP-F and FovP-R, 396-bp amplicon), respectively, in a duplex manner. This method amplified either the 583-bp band or the 396-bp band from all of the 107 $F$. oxysporum and $1 F$. verticillioides isolates tested. The FovP-F and FovP-R pair positively identified all $F$. oxysporum f. sp. vasinfectum isolates other than $\mathrm{Cal}$ race 4 which contained the Tfol insertion. The FovP-F and FovT-R pair is highly specific for the Cal race 4 isolates. The remaining 12 fungal isolates, including more distantly related Fusarium spp. and other soil-inhabiting fungal species, did not yield a product when tested with our primers. This failure was due to the specificity built into the primer's sequence for the $F$. oxysporum and closely related isolates. We used $E F-1 \alpha$ primers to produce an amplicon (data not shown) and verify the amenability of the fungal DNA used.

First characterized in F. oxysporum f. sp. langenaiae, Tfol (transposon of $F$. oxysporum) is a transposable element, 2,763 bp long, encoding a 777-amino-acid transposase (Okuda et al. 1998). The element belongs to the $h A T$ family of class II transposons (DNA transposon) because it contains common $h A T$ structural characteristics such as 15-bp terminal inverted repeats, 8-bp target site duplications, and a variable number (nine in $F$. oxysporum $\mathrm{f}$. sp. langenaiae) of subterminal direct repeats (Fig. 1) (Kempken and Windhofer 2001; Okuda et al. 1998). The Tfol element used in this detection study shares all of these features and greater than $99 \%$ sequence identity to the one previously reported.

Evidence suggests that Tfol is a potentially active transposon (Okuda et al. 1998). Though there are some concerns on the position stability of active DNA transposons in a given genome due to its cutand-paste transposition mechanism (Lievens et al. 2008), they are still used for pathogen detection. These include transposons Fot1, Fot3, Hop, and Impala in Fusarium spp. (Daboussi and Capy 2003). Thus, PCR amplification of the unique Fotl insertion junction has been used to specifically distinguish the date palm pathogen F. oxysporum f. sp. albedinis from other formae speciales (Fernandez et al. 1998). Furthermore, the Fot1 and Impala insertion junctions were used to discriminate among different races within the carnation wilt pathogen $F$. oxysporum f. sp. dianthi (Chiocchetti et al. 1999). More recently, Suga et al. (2013) identified both DNA transposons and retrotransposons Fot3, Foxy, Han, Hop, Hornet1, Impala, and Skippy among isolates of $F$. oxysporum $\mathrm{f}$. sp. fragariae and utilized the genomic region between Han and Skippy to distinguish the strawberry pathogen from other nonpathogenic Fusarium strains and five other formae speciales of $F$. oxysporum.

Retrotransposons (class I) transpose via a copy-and-paste mechanism; therefore, they are considered relatively more stable in the genome compared with DNA transposons (class II). The retroelements and techniques based on the retroelements, such as interretrotransposon sequence-characterized amplification region, have also been used to differentiate and detect a wide array of $F$. oxysporum isolates at either forma speciales or races levels for monophyletic groups

A

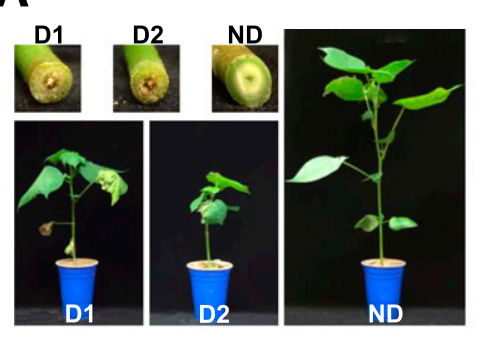

B
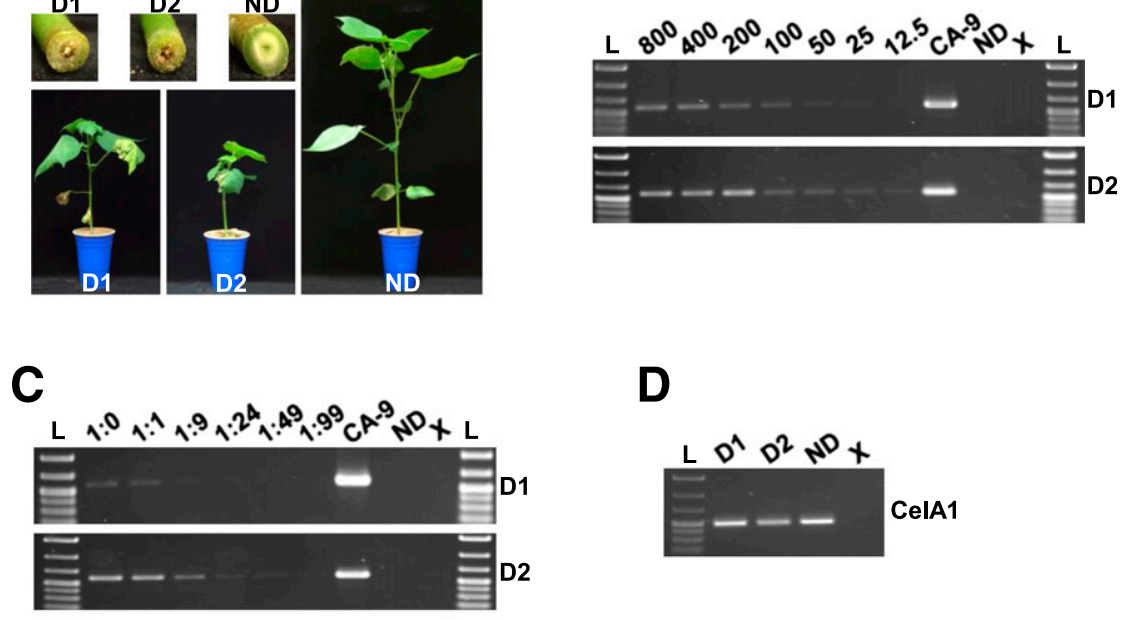

D

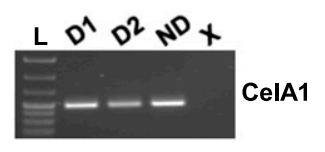

E

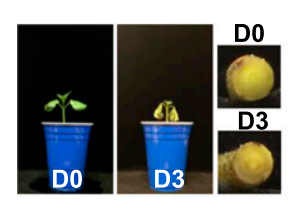

$\mathbf{F}$

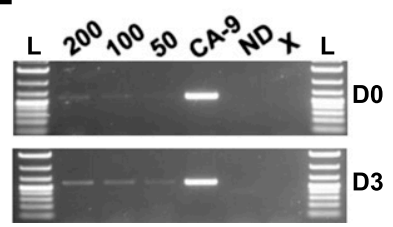

Fig. 4. Detection of Fusarium oxysporum f. sp. vasinfectum Cal race 4 in infected cotton plants with the multiplex polymerase chain reaction (PCR). A, Representative 6-week-old cotton plants used in this study: D1 (disease index 1 on a 0-to-4 scale, with 0 no disease and 4 plant dead) and D2 (disease index 2) are plants grown in soil drenched with CA-9 conidia $\left(5 \mathrm{ml}\right.$ of $10^{6}$ conidia $\mathrm{ml}^{-1}$ ) and exhibit Fusarium wilt disease symptoms, while ND is a noninfected negative control plant. Total plant DNA was extracted from stem tissue $(1 \mathrm{~cm}$ long) just above ground level. B, DNA from F. oxysporum f. sp. vasinfectum-infected plants at concentrations ranging from 800 to $12.5 \mathrm{ng}$ per $25-\mu \mathrm{l}$ reaction assayed with the PCR multiplex system. D1 in upper panel, D2 in lower panel. C, Phosphate: $\mathrm{H}^{+}$symporter (PHO)-Tfo1 detection in total infected plant DNA diluted to the indicated ratios with noninoculated ND plant DNA. D1 in upper panel, D2 in lower panel. D, DNA amenability of total plant DNA from D1 (lane 1), D2 (lane 2), and ND (lane 3) plants by PCR amplification of the plant cellulose synthase A1 gene. E, Representative 3-week-old CA-9-infected cotton plants displaying no disease symptoms (D0) and displaying disease score of 3 (D3). F, F. oxysporum f. sp. vasinfectum-infected plant DNA at concentrations of 200 to $50 \mathrm{ng}$ per $25-\mu l$ reaction assayed with the PCR multiplex system. D0 in upper panel, D3 in lower panel. For C, D, and F, CA-9 DNA from fungal culture was used as positive control whereas, for B, C, D, and F, ND DNA was used as a plant negative control. DNA from controls was used at $50 \mathrm{ng}$ per reaction. $X$ represents a reaction-negative (no DNA added) control while $L$ represents a 1-kb-plus DNA ladder. 
within respective levels (Lievens et al. 2008). However, retrotransposon stability may still be affected by the propensity of transposon elements to insert into existing elements, forming nested structures (Hua-Van et al. 2000). Because most transposons in $F$. oxysporum are DNA transposons (Dufresne et al. 2011; Hua-Van et al. 2000), they provide more target options compared with retroelements for use in pathogen differentiation in this species complex.

The developed method is also applicable for the in planta detection of Cal race 4 isolates with high specificity and sensitivity. The specificity of the assay was retained even at high concentrations of plant DNA. The sensitivity of detection was dependent on the disease severity as well as the age of the infected plants. The detection limit is lower for the more severely infected plants (Fig. 4B and F). Likewise, the 6-week-old infected plants had a lower detection limit than the 3 -week-old infected plants with similar disease ratings, indicating that less extensive colonization by the pathogen during early stages of the infection process can still cause severe wilting symptoms. The system is even capable of detecting the presence of the pathogen in the plants before any external symptoms appear (Fig. 4F). For pure fungal DNA from isolate CA-9 and the reference isolate of race 4, a detection limit of $5 \mathrm{pg} / \mu \mathrm{l}$ for the $T f \circ \mathrm{l}$ insertion junction and $40 \mathrm{pg} / \mu \mathrm{l}$ for the undisrupted $P H O$, respectively, have been determined.

In conclusion, a method was developed to distinguish the highly virulent $F$. oxysporum f. sp. vasinfectum $\mathrm{Cal}$ race 4 isolates from other $F$. oxysporum f. sp. vasinfectum genotypes, including the race 4 reference isolate from India and other Fusarium spp. and soilborne fungi. The method involved screening for the transposable element $T f o l$ within the coding sequence of the $P H O$ gene of $F$. oxysporum f. sp. vasinfectum. The multiplex PCR assay described here is reliable in detecting Cal race 4 isolates, with no cross reactivity found to date. Therefore, the method provides a specific and reliable tool for the identification and detection of $F$. oxysporum f. sp. vasinfectum $\mathrm{Cal}$ race 4 isolates.

\section{Acknowledgments}

We thank R. M. Davis, University of California, Davis, for providing fungal isolates with CA or MD designations; K. S. Lawrence, Auburn University, for providing fungal isolates with KL designation; F. K. Crutcher for several nonFusarium isolates; and the Agricultural Research Service Culture Collection (NRRL) and Fungal Genetics Stock Center (Kansas City, MO) for access to their culture collections.

\section{Literature Cited}

Abo, K., Klein, K. K., Edel-Hermann, V., Gautheron, N., Traore, D., and Steinberg, C. 2005. High genetic diversity among strains of Fusarium oxysporum f. sp. vasinfectum from cotton in Ivory Coast. Phytopathology 95:1391-1396.

Alabouvette, C., Broise, D., Lemanceau, P., Couteaudier, Y., and Louvet, J. 1987. Use of non-pathogenic strains of Fusarium to control Fusarium diseases: Present situation in practice. Bull. OEPP 17:665-674.

Anonymous. Fusarium comparative sequencing project. Online publication. Broad Institute of Harvard and MIT. (http://www.broadinstitute.org/)

Armstrong, G. M., and Armstrong, J. K. 1960. American, Egyptian, and Indian cotton-wilt Fusaria: Their pathogenicity and relationship to other wilt Fusaria. Tech. Bull. U.S. Dep. Agric. 1219:1-19.

Armstrong, G. M., and Armstrong, J. K. 1978. A new race (race 6) of the cottonwilt Fusarium from Brazil. Plant Dis. Rep. 62:421-423.

Armstrong, J. K., and Armstrong, G. M. 1958. A race of the cotton-wilt Fusarium causing wilt of Yelredo soybean and flue-cured tobacco. Plant Dis. Rep. 42: 147-151.

Bennett, R. S., Scott, T. Z., Lawrence, K. S., and Lawrence, G. W. 2013. Sequence characterization of race 4-like isolates of Fusarium oxysporum from Alabama and Mississippi. J. Cotton Sci. 17:125-130.

Chen, Q., Ji, X., and Sun, W. 1985. Identification of races of cotton wilt Fusarium in China. Sci. Agric. Sin. 6:1-6.

Chiocchetti, A., Bernardo, I., Daboussi, M. J., Garibaldi, A., Gullino, M. L., Langin, T., and Migheli, Q. 1999. Detection of Fusarium oxysporum f. sp. dianthi in carnation tissue by PCR amplification of transposon insertions. Phytopathology 89:1169-1175.

Coleman, J. J., Rounsley, S. D., Rodriguez-Carres, M., Kuo, A., Wasmann, C. C., Grimwood, J., Schmutz, J., Taga, M., White, G. J., Zhou, S., Schwartz, D. C., Freitag, M., Ma, L. J., Danchin, E. G., Henrissat, B., Coutinho, P. M., Nelson, D. R., Straney, D., Napoli, C. A., Barker, B. M., Gribskov, M., Rep, M., Kroken, S., Molnar, I., Rensing, C., Kennell, J. C., Zamora, J., Farman, M. L., Selker, E. U., Salamov, A., Shapiro, H., Pangilinan, J., Lindquist, E., Lamers, C., Grigoriev, I. V., Geiser, D. M., Covert, S. F., Temporini, E., and
Vanetten, H. D. 2009. The genome of Nectria haematococca: Contribution of supernumerary chromosomes to gene expansion. PLoS Genet. 5:e1000618.

Correll, J. C., Klittich, C. J. R., and Leslie, J. F. 1987. Nitrate non-utilizing mutants of Fusarium oxysporum and their use in vegetative compatibility tests. Phytopathology 77:1640-1646.

Crutcher, F. K., Doan, H. K., Bell, A. A., Davis, R. M., Stipanovic, R. D., Nichols, R. L., and Liu, J. 2016. Evaluation of methods to detect the cotton wilt pathogen Fusarium oxysporum f. sp. vasinfectum race 4. Eur. J. Plant Pathol. 144 225-230.

Crutcher, F. K., Liu, J., Puckhaber, L. S., Stipanovic, R. D., Duke, S. E., Bell, A. A., Williams, H. J., and Nichols, R. L. 2014. Conversion of fusaric acid to fusarinol by Aspergillus tubingensis: A detoxification reaction. J. Chem. Ecol. 40:84-89.

Daboussi, M. J., and Capy, P. 2003. Transposable elements in filamentous fungi. Annu. Rev. Microbiol. 57:275-299.

Dave, K. I., Lauriano, C., Xu, B. W., Wild, J. R., and Kenerley, C. M. 1994. Expression of organophosphate hydrolase in the filamentous fungus Gliocladium virens. Appl. Microbiol. Biotechnol. 41:352-358.

Davis, R. D., Moore, N. Y., and Kochman, J. K. 1996. Characterisation of a population of Fusarium oxysporum f. sp. vasinfectum causing wilt of cotton in Australia. Aust. J. Agric. Res. 47:1143-1156.

Davis, R. M., Colyer, P. D., Rothrock, C. S., and Kochman, J. K. 2006. Fusarium wilt of cotton: Population diversity and implication for management. Plant Dis. 90:692-703.

Davis, R. M., Kim, Y., DeVay, J. E., Smith, S. N., and Hutmacher, R. B. 2003. Characterization of California isolates of Fusarium oxysporum f. sp. vasinfectum. Pages 191-196 in: Beltwide Cotton Conferences. P. Dugger and D. Richter, eds. The Cotton Foundation, San Antonio, TX.

Di Pietro, A., Madrid, M. P., Caracuel, Z., Delgado-Jarana, J., and Roncero, M. I. G. 2003. Fusarium oxysporum: Exploring the molecular arsenal of a vascular wilt fungus. Mol. Plant Pathol. 4:315-325.

Di Pietro, A., and Roncero, M. I. 1996. Purification and characterization of an exo-polygalacturonase from the tomato vascular wilt pathogen Fusarium oxysporum f. sp. lycopersici. FEMS Microbiol. Lett. 145:295-299.

Doan, H. K., Zhang, S., and Davis, R. M. 2014. Development and evaluation of AmplifyRP Acceler8 diagnostic assay for the detection of Fusarium oxysporum f. sp. vasinfectum race 4 in cotton. Plant Health Prog. 15:48-52.

Dufresne, M., Lespinet, O., Daboussi, M. J., and Hua-Van, A. 2011. Genome-wide comparative analysis of pogo-like transposable elements in different Fusarium species. J. Mol. Evol. 73:230-243.

Fernandez, D., Assigbetse, K., Dubois, M. P., and Geiger, J. P. 1994. Molecular characterization of races and vegetative compatibility groups in Fusarium oxysporum f. sp. vasinfectum. Appl. Environ. Microbiol. 60:4039-4046.

Fernandez, D., Ouinten, M., Tantaoui, A., Geiger, J. P., Daboussi, M. J., and Langin, T. 1998. Fot 1 insertions in the Fusarium oxysporum f. sp. albedinis genome provide diagnostic PCR targets for detection of the date palm pathogen. Appl. Environ. Microbiol. 64:633-636.

Gordon, T. R., and Martyn, R. D. 1997. The evolutionary biology of Fusarium oxysporum. Annu. Rev. Phytopathol. 35:111-128.

Holmes, E. A., Bennett, R. S., Spurgeon, D. W., Colyer, P. D., and Davis, R. M 2009. New genotypes of Fusarium oxysporum f. sp. vasinfectum from the Southeastern United States. Plant Dis. 93:1298-1304.

Hua-Van, A., Daviere, J. M., Kaper, F., Langin, T., and Daboussi, M. J. 2000 Genome organization in Fusarium oxysporum: Clusters of class II transposons. Curr. Genet. 37:339-347.

Ibrahim, F. M. 1966. A new race of cotton-wilt Fusarium in the Sudan Gezira. Emp. Cotton Grow. Rev. 43:296-299.

Kempken, F., and Windhofer, F. 2001. The hAT family: A versatile transposon group common to plants, fungi, animals, and man. Chromosoma 110:1-9.

Kim, Y., Hutmacher, R. B., and Davis, R. M. 2005. Characterization of California isolates of Fusarium oxysporum f. sp. vasinfectum. Plant Dis. 89:366-372.

Kistler, H. C., Momol, E. A., and Benny, U. 1991. Repetitive genomic sequences for determining relatedness among strains of Fusarium oxysporum. Phytopathology 81:331-336.

Leslie, J. F. 1993. Fungal vegetative compatibility. Annu. Rev. Phytopathol. 31: 127-150.

Li, H., Luo, J., Hemphill, J. K., Wang, J. T., and Gould, J. H. 2001. A rapid and high yielding DNA miniprep for cotton (Gossypium spp.). Plant Mol. Biol. Rep. 19:183.

Lievens, B., Rep, M., and Thomma, B. P. H. J. 2008. Recent developments in the molecular discrimination of formae speciales of Fusarium oxysporum. Pest Manage. Sci. 64:781-788.

Liu, J., Bell, A. A., Wheeler, M. H., Stipanovic, R. D., and Puckhaber, L. S. 2011 Phylogeny and pathogenicity of Fusarium oxysporum isolates from cottonseed imported from Australia into California for dairy cattle feed. Can. J. Microbiol. 57:874-886.

Ma, L. J., Shea, T., Young, S., Zeng, Q., and Kistler, H. C. 2014. Genome sequence of Fusarium oxysporum f. sp. melonis strain NRRL 26406, a fungus causing wilt disease on melon. Genome Announc. 2:e00730-14.

Nirenberg, H. I., Ibrahim, G., and Michail, S. H. 1994. Race identity of 3 isolates of Fusarium oxysporum Schlecht $\mathrm{f}$. sp. vasinfectum (Atk) Snyd and Hans from Egypt and the Sudan. Z. Pflanzenkrankh. Pflanzenschutz 101: 594-597. 
Okuda, M., Ikeda, K., Namiki, F., Nishi, K., and Tsuge, T. 1998. Tfol: An Ac-like transposon from the plant pathogenic fungus Fusarium oxysporum. Mol. Gen. Genet. 258:599-607.

Persson, B. L., Petersson, J., Fristedt, U., Weinander, R., Berhe, A., and Pattison, J. 1999. Phosphate permeases of Saccharomyces cerevisiae: Structure, function and regulation. Biochim. Biophys. Acta 1422:255-272.

Puhalla, J. E. 1985. Classification of strains of Fusarium oxysporum on the basis of vegetative compatibility. Can. J. Bot. 63:179-183.

Puhalla, J. E., and Hummel, M. 1983. Vegetative compatibility groups within Verticillium dahliae. Phytopathology 73:1305-1308.

Puhalla, J. E., and Spieth, P. T. 1983. Heterokaryosis in Fusarium moniliforme. Exp. Mycol. 7:328-335.

Saitou, N., and Nei, M. 1987. The neighbor-joining method-A new method for reconstructing phylogenetic trees. Mol. Biol. Evol. 4:406-425.

Skovgaard, K., Nirenberg, H. I., O’Donnell, K., and Rosendahl, S. 2001. Evolution of Fusarium oxysporum f. sp. vasinfectum races inferred from multigene genealogies. Phytopathology 91:1231-1237.

Smith, S. N., and Snyder, W. C. 1975. Persistence of Fusarium oxysporum f. sp. vasinfectum in fields in absence of cotton. Phytopathology 65:190-196.

Snyder, W. C., and Hansen, H. N. 1940. The species concept in Fusarium. Am. J. Bot. 27:64-67.

Stakheev, A. A., Khairulina, D. R., Ryazantsev, D. Y., and Zavriev, S. K. 2013. Phosphate permease gene as a marker for the species-specific identification of the toxigenic fungus Fusarium cerealis. Russ. J. Bioorganic Chem. 39: 153-160.
Suga, H., Hirayama, Y., Morishima, M., Suzuki, T., Kageyama, K., and Hyakumachi, M. 2013. Development of PCR primers to identify Fusarium oxysporum f. sp. fragariae. Plant Dis. 97:619-625.

Tamura, K., Dudley, J., Nei, M., and Kumar, S. 2007. MEGA4: Molecular evolutionary genetics analysis (MEGA) software version 4.0. Mol. Biol. Evol. 24:1596-1599.

Thompson, J. D., Higgins, D. G., and Gibson, T. J. 1994. Clustal-W-Improving the sensitivity of progressive multiple sequence alignment through sequence weighting, position-specific gap penalties and weight matrix choice. Nucleic Acids Res. 22:4673-4680

Woloshuk, C. P., Seip, E. R., Payne, G. A., and Adkins, C. R. 1989. Genetic transformation system for the aflatoxin-producing fungus Aspergillus flavus. Appl. Environ. Microbiol. 55:86-90.

Xin, Z. G., Velten, J. P., Oliver, M. J., and Burke, J. J. 2003. High-throughput DNA extraction method suitable for PCR. Biotechniques 34:820-826.

Yang, M. E. 2006. PCR-based detection of Fusarium oxysporum f. sp. vasinfectum race 4 and the effect of Fusarium oxysporum f. sp. vasinfectum race 4 soil density on Fusarium wilt disease development in cotton. University of California, Davis.

Yang, M. E., Davis, R. M., and Hutmacher, R. B. 2006. Fusarium wilt of cotton in California: Characterization and PCR-based detection of race 4. Pages 93-96 in: Beltwide Cotton Conferences. S. Boyd, M. Huffman, and B. Robertson, eds. The Cotton Foundation, San Antonio, TX.

Ye, J., Coulouris, G., Zaretskaya, I., Cutcutache, I., Rozen, S., and Madden, T. L. 2012. Primer-BLAST: A tool to design target-specific primers for polymerase chain reaction. BMC Bioinf. 13:134. 